\title{
Small Intestinal Adenosquamous
}

\section{Carcinoma}

National Cancer Institute

\section{Source}

National Cancer Institute. Small Intestinal Adenosquamous Carcinoma. NCI Thesaurus.

Code C43535.

A carcinoma that arises from the small intestine. It is composed of malignant glandular cells and malignant squamous cells. 